\title{
MEWUJUDKAN NEW PUBLIC MANAGEMENT TERHADAP INDISIPLINER MAHASISWA MELALUI PENERAPAN AbCD (ABSEN CAP DRIJI)
}

\author{
Hayat $^{1}$, Abid Zamzami ${ }^{2}$ \\ ${ }^{1}$ Fakultas IImu Administrasi Universitas Islam Malang \\ email: hayat@unisma.ac.id \\ ${ }^{2}$ Fakultas Hukum Universitas Islam Malang \\ email: abidzamzami@unisma.ac.id
}

\begin{abstract}
University of Islam Malang (UNISMA) as a public institution has a goal to be achieved. One of the goals that Unisma wants to achieve is to produce superior and qualified students. To achieve this goal, Unisma should apply new policies in terms of New Public Management (NPM). In NPM, Unisma should apply Absen Cap Driji / Absensi Sidik Jari $(A b C D)$ machines as a solution to overcome student indiscipline. Need to know, so far the form of student indiscipline in Unisma has always increased every year. This form of indiscipline, among others; 1) Often come late, 2) Do not do assignments, 3) Often do not enter without reason, 4) D3C (Come, Sit, Listen, and underestimate the lecture. If the form of student indiscipline is unchecked, it is feared that students are increasingly out of control, affecting other students, even Unisma fails to achieve the goal of creating excellent and high quality students. So that $A b C D$ machines are needed in order to implement NPM while minimizing student indiscipline. $A b C D$ is an absent machine that uses fingerprints so as to reduce dishonesty done by students in terms of college attendance. $A b C D$ replaces the previous presence system which is still manual and easily manipulated. This $A b C D$ program is expected to provide benefits in the long term, those are: 1) To discipline Unisma students by applying AbCD machines, 2) To develop IT in Unisma so as not to be left behind, 3) To avoid conflicts between students and students, and students with lecturers at Unisma. The methods used in implementing AbCD machines are: 1) Pre-Program Analysis, 2) Location Survey, 3) Licensing Administration, 4) Procurement of Goods, 5) Material Preparation, 6) Recruitment of Facilitators and Participants, 7) Lecturer debriefing, 8) Student Counseling, 9) Utilization of $A b C D$, and 10) Evaluation. Which of the ten methods of implementation has been completed with the budget and implementation schedule.
\end{abstract}

Keywords: new public management, indiscipline, AbCD machines model

\begin{abstract}
ABSTRAK
Universitas Islam Malang (UNISMA) sebagai lembaga publik memiliki tujuan yang ingin dicapai. Salah satu tujuan yang ingin dicapai Unisma adalah menghasilkan mahasiswa yang unggul dan berkualitas. Untuk mencapai tujuan ini, Unisma harus menerapkan kebijakan baru dalam hal Manajemen Publik Baru (NPM). Di NPM, Unisma harus menerapkan mesin Absen Cap Driji/Absensi Sidik Jari (AbCD) sebagai solusi untuk mengatasi ketidakdisiplinan mahasiswa. Perlu diketahui, sejauh ini bentuk ketidakdisiplinan mahasiswa di Unisma selalu meningkat setiap tahun. Bentuk
\end{abstract}


ketidakdisiplinan ini antara lain; 1) sering datang terlambat, 2) tidak mengerjakan tugas, 3) sering tidak masuk tanpa alasan, 4) D3C (datang, duduk, dengar, dan remehkan kuliah. Jika bentuk ketidakdisiplinan mahasiswa tidak dicentang, dikhawatirkan bahwa mahasiswa semakin di luar kendali, bisa mempengaruhi mahasiswa lainnya, serta berdampak terhadap peningkatan kualitas lulusan, sehingga mesin AbCD diperlukan untuk menerapkan NPM untuk meminimalisir ketidakdisiplinan mahasiswa. AbCD adalah mesin absen yang menggunakan sidik jari, sehingga untuk mengurangi ketidakjujuran yang dilakukan oleh mahasiswa dalam hal kehadiran di dalam mengikuti proses belajar mengajar. AbCD menggantikan sistem kehadiran sebelumnya yang masih manual dan mudah dimanipulasi. Program AbCD ini diharapkan dapat memberikan manfaat dalam jangka panjang, yaitu: 1) untuk mendisiplinkan mahasiswa Unisma dengan menerapkan mesin $A b C D$, 2) untuk mengembangkan IT di Unisma agar tidak ketinggalan, 3) untuk menghindari konflik antara mahasiswa dan mahasiswa, dan mahasiswa dengan dosen di Unisma. Metode yang digunakan dalam mengimplementasikan mesin AbCD adalah: 1) analisis pra program, 2) survei lokasi, 3) administrasi perizinan, 4) pengadaan barang, 5) penyiapan bahan, 6) perekrutan fasilitator dan peserta, 7) pembekalan dosen, 8) konseling mahasiswa, 9) pemanfaatan $A b C D$, dan 10) evaluasi. Penerapan metode tersebut dilakukan berdasarkan ketentuan, anggaran dan jadwal yang terlah dibuat.

Kata Kunci: manajemen publik baru, ketidakdisiplinan, model mesin AbCD

\section{PENDAHULUAN}

Fakultas IImu Administrasi (FIA) pada 27 Maret 1983 ini mulai beroperasi dengan jurusan Administrasi Negara dan Administrasi Niaga. Sejak 31 Maret 2005 Universitas Islam Malang telah membuka Fakultas Kedokteran dengan konsentrasi pada keanekaragaman hayati sebagai penunjang pengobatan

FIA UNISMA didirikan tanggal 27 Maret 1983 untuk menjawab tantangan persaingan global di bidang Publik dan Bisnis saat ini dan masa mendatang. FIA UNISMA memiliki komitmen menyelenggarakan pendidikan untuk mempersiapkan dan mencetak sumber daya manusia yang profesional, handal dan memiliki performansi imtaq dalam menangani masalah- masalah kebijakan publik, otonomi daerah, ekonomi politik, konsultan publik, kebijakan bisnis, konsultan manajemen dan analisis peluang pasar. FIA UNISMA juga berkomitmen untuk menyempurnakan penyelenggaraan pendidikan yang sesuai dengan perkembangan teknologi dan kebutuhan masyarakat dengan mewujudkan pemimpin (administrator) yang handal, cerdas, kreatif dan berakhlaqul karimah.

FIA UNISMA mempunyai dua program studi, yaitu Program Studi IImu Administrasi Negara dan Niaga. Semua program studi telah menerapkan Kurikulum Berbasis Kompetensi yang diselaraskan dengan Kerangka Kualifikasi Nasional Indonesia (KKNI).

Administrasi adalah bagian yang tidak dapat dipisahkan dari roda pemerintahan. Seiring berjalannya waktu, administrasi memiliki berbagai pergeseran, dari yang semula otoritas tunggal dalam implementasi kebijakan publik, berubah menjadi fasilitator masyarakat. Begitu pula dengan paradigma 
administrasi publik yang juga selalu berkembang, mulai dari Old Public Administration (OPA), New Public Management (NPM), sampai dengan New Public Service (NPS). Khusus untuk NPM, sebagian ahli administrasi mengakui bahwa NPM telah merombak tatanan administrasi publik yang lebih menekankan bagaimana seharusnya institusi publik dijalankan.

Dalam menjalankan institusi publik, NPM seharusnya memperlakukan publik sebagai pelanggan (costumer). Pimpinan organisasi publik harus menemukan cara-cara baru untuk mencapai hasil. Untuk mencapai hasil NPM seharusnya seperti yang di ungkapkan Hood $(1991)^{1}$; (1) Usaha untuk memperlambat atau mengubah pertumbuhan (slow down or reverse goverment growth) pemerintah dalam hal pengeluaran dan pelayan publik yang telah berlebihan; (2) pergerakan ke arah swastanisasi dan semi privatisasi termasuk keluar dari institusi pemerintah dengan memperbarui penekanan dari level terbawah dalam penyedia layanan; (3) pengembangan automation khususnya dalam teknologi informasi dan dalam produksi dan distribusi pelayanan publik; dan (4) pengembangan suatu agenda yang lebih internasional, yang berfokus pada isu-isu umum manajemen publik, rancangan kebijakan, bentuk keputusan dan kerja sama antar pemerintah.

Berkaitan dengan keempat pernyataan tersebut, seharusnya institusi publik dapat mengatasi berbagai permasalahan yang kerap kali muncul. Termasuk salah satu permasalahan yang akhir-akhir ini sedang gencar, yakni : ketidakdisiplinan mahasiswa di institusi publik. Termasuk ketidakdisiplinan mahasiswa di Universitas Islam Malang (Unisma). Padahal Unisma telah berkomitmen penuh dalam mengatasi permasalahan tersebut. Di mana salah satu cara yang dilakukan adalah dengan penerapan Absen Cap Driji (AbCD). AbCD menitik beratkan pada pendisiplinan para mahasiswa di Unisma. Selain itu dengan adanya mesin $A b C D$, para mahasiswa diharapkan sadar akan pentingnya pendidikan dan lebih bertanggung jawab.

Mahasiswa memiliki peran sentral dalam kehidupan Universitas. Sudah menjadi tugas dan tanggung jawab Unisma untuk dapat mencetak lulusan yang berkualitas dan dapat berkiprah ditingkat nasional maupun internasional. Pembentukan mahasiswa yang berkualitas merupakan salah satu ukuran keberhasilan suatu Universitas. Dalam hal ini mahasiswa memiliki lima fungsi, yaitu agen of social control (sebagai penyampai kebenaran); agen of change (sebagai agen perubahan); iron stop (sebagai generasi penerus masa depan); moral force (sebagai orang yang bermoral baik); dan direct of change (sebagai pembawa perubahan langsung karena SDMnya yang memadai).

Mitra dari pengabdian ini adalah mahasiswa Fakultas IImu Administrasi Universitas Islam Malang yang terdiri dari Program Studi IImu Administrasi Niaga dan Bisnis.

Kenyataan ini memberikan implikasi yang signifikan terhadap kebutuhan mahasiswa dalam meningkatkan kedisiplinannya. Karena banyak mahasiswa di Unisma yang tidak menyadari akan fungsinya. Hal ini dapat dilihat dari hasil observasi penulis di Fakultas IImu Administrasi, di kelas negara dan 
niaga. Di kelas tersebut, ditemukan bahwa \pm 12 dari 120 mahasiswa kelas negara dan niaga, tidak disiplin dalam perkuliahan. Hal ini menunjukkan bahwa angka ketidakdisiplinan mahasiswa $\pm 10 \%$. Apabila $10 \%$ tersebut dijadikan ratarata dari kisaran ketidakdisiplinan mahasiswa dalam fakultas, dan disetiap fakultas terdapat 100 mahasiswa, maka di Unisma yang terdapat 11 fakultas akan didapatkan 110 mahasiswa yang melakukan tindakan ketidakdisiplinan dalam satu periode angkatan.

Selebihnya dari angka tersebut, masih dapat menjalankan kewajibannya sebagai mahasiswa dan bertanggung jawab. Perlu diketahui pula bahwa kebanyakan mahasiswa di Universitas Islam Malang adalah mereka yang tidak diterima di PTN/PTS favorit. Sehingga mahasiswa di Unisma yang tidak disiplin seperti menjadi sebuah ironi yang wajar. Bentuk ketidakdisiplinan mahasiswa ini diantaranya sering datang terlambat, tidak mengerjakan tugas, sering tidak masuk tanpa alasan, D3C (datang, duduk, dengar, dan catat) dan menyepelekan kuliah

Sementara faktor-faktor yang menyebabkan ketidakdisiplinan mahasiswa Unisma, antara lain: Pertama, salah jurusan. Ini merupakan faktor terbesar penyebab malas kuliah. Banyak mahasiswa yang salah jurusan dengan berbagai alasan, seperti paksaan dari orang tua untuk masuk jurusan tertentu atau karena ikut-ikutan teman dan berbagai alasan lainnya. Sebaiknya, dari awal memilih jurusan sesuai minat dan bakat. Jika sudah terlanjur, jalani saja sampai bisa lulus. Kalau diperhatikan, banyak lulusan sarjana yang bidang kerjanya tidak sesuai dengan disiplin ilmu mereka saat kuliah. Contohnya : lulusan ilmu pertanian bekerja di Bank, lulusan bahasa dan sastra menjadi pengusaha.

Kedua, sudah tahu 'duit'. Untuk mahasiswa yang mempunyai sampingan kerja atau bisnis, kadang-kadang mereka terlalu asyik bekerja dan menghasilkan uang, sampai saat dimana waktu kuliah dan waktu kerja bertabrakan, mereka lebih memilih bekerja. Akhirnya, kuliah menjadi terabaikan.

Ketiga, salah dalam berteman. Bagaimanapun, teman adalah faktor penyemangat kuliah. Dalam perkuliahan, dibutuhkan teamwork yang solid. Salah satu kuncinya yaitu memiliki teman yang solid dan menjalani aktivitas kuliah tersebut. Saat mahasiswa tidak menemukan teman yang tepat, maka mahasiswa mulai merasakan jenuh terhadap kegiatan yang dilakukan di kampus. Mulailah timbul perasaan malas untuk kuliah.

Keempat, jam kuliah terlalu pagi. Alasan ini adalah alasan klasik yang sampai sekarang masih menjadi senjata andalan mahasiswa pemalas. Ada perasaan sangat berat untuk bangun pagi, mandi pagi, lalu kuliah pagi. Biasanya, alasan ini seringkali dipakai oleh para mahasiswa laki-laki yang waktunya banyak di gunakan untuk hal-hal yang kurang penting seperti bergadang.

Kelima, sdanya masalah keluarga. Masalah keluarga dapat berpengaruh besar terhadap semangat untuk menjalani perkuliahan bagi 
mahasiswa. Saat mulai merasa kurang di mendapat perhatian dari keluarga terutama orang tua, maka minat belajar mahasiswa akan menurun. Anak akan berfikir bahwa belajar ataupun tidak, orang tua juga tidak memiliki rasa peduli. Ini adalah tanggung jawab orang tua.

Keenam, bosan kuliah. Ini adalah alasan yang sering dipakai oleh mahasiswa yang lupa tujuan utama dirinya merantau untuk kuliah. Efeknya adalah hanya membuang-buang waktu yang seharusnya digunakan untuk kuliah sehingga menunda waktu kelulusan yang menyebabkan kemarahan orang tua.

Ketujuh, masalah cinta. Masalah hubungan cinta, terutama masalah yang berhubungan dengan hati menyebabkan mahasiswa malas melakukan kuliah. Mahasiswa cenderung menghabiskan waktu untuk berpacaran, melamun, menangis dan lain sebagainya tanpa memperdulikan betapa pentingnya menuntut ilmu.

Kedelapan, sering begadang. Jika mahasiswa terlalu sering begadang akan menimbulkan rasa letih, tidak bersemangat, cepat marah dan tidak dapat konsentrasi terhadap apa yang sedang jalani. Rasa kantuk di kelas yang luar biasa juga membuat mahasiswa bermalas-malasan, konsentrasi buyar dan akhirnya kuliah hanya sekedar duduk dan mendengar apa yang dosen jelaskan tanpa memahami matteri yang disampaikan.

Kesembilan, dosen yang membosankan. Dosen yang membosankan adalah keluhan yang seringkali menjangkit para mahasiswa. Mahasiswa semangat di mata kuliah ini, tapi malas ikut mata kuliah itu. Penyebabnya karena sang Dosen sangat membosankan dan tidak benar-benar niat mengajar.

Kesepuluh, keterbatasan ekonomi. Ekonomi yang terbatas seringkali membuat mahasiswa minder untuk kuliah. Mahasiswa yang seperti ini biasanya tidak sanggup untuk menyelesaikan proses pembelajaran sampai lulus. Kurangnya pengawasan dari Dosen. Minimnya pengawasan dari Dosen membuat mahasiswa bertindak sesuka hati. Tindakan mahasiswa ini kemudian menjadi hal yang lumrah mereka lakukan sebab tidak ada tindak lanjut dari Dosen.

Kesebelas, pengaruh perkembangan TIK. Berkembangnya TIK menyebabkan mahasiswa salah dalam memanfaatkannya. Mahasiswa lebih asyik dengan dunia TIK tanpa memikirkan akibatnya. Sebagai contoh; maraknya penggunaan gadget seperti; tablet, menyebabkan mahasiswa lebih berkonsentrasi menggunakan tablet tersebut daripada mendengarkan materi yang diajarkan oleh Dosen.

Merujuk pada beberapa permasalahan yang berhubungan dengan kedisiplinan mahasiswa FIA Unisma di atas, maka Peneliti mencoba berinovasi dengan mengenalkan penerapan $A B C D$ (Absen Cap DrijiAbsen Sidik Jari) sebagai perwujudan new public management (npm) dan alternatif ketidakdisiplinan Mahasiswa di Universitas Islam Malang. Oleh karena itu, maka rumusan masalahnya adalah bagaimana cara meningkatkan kesadaran 
Mahasiswa akan pentingnya presensi dalam menciptakan kedisiplinan dan keteraturan proses belajar mengajar.

Sedangkan tujuan dari program ini adalah dapat memberikan pengetahuan kepada mahasiswa Fakultas IImu Administrasi Universitas Islam Malang tentang pentingnya presensi dalam menciptakan kedisiplinan dan keteraturan dalam proses belajar mengajar. Disamping itu, memberikan pemahaman tentang inovasi model presensi baru yang pengabdi lakukan. Hal ini juga perlu disampaikan tujuan dari penerapan AbCD ini dalam rangka untuk meningkatkan kualitas mahasiswa dalam menciptakan pendidikan karakter.

Diharapkan dapat menciptakan pendidikan karakter yang berkualitas dan menjadikan output mahasiswa Fakultas IImu Administrasi Unisma yang mempunyai daya saing tinggi, kualitas visioner dan inovasi yang memadai serta menjadi ungggulan dalam kehidupan masyarakat yang lebih baik dan bermanfaat bagi kehidupan masyarakat

\section{METODE PELAKSANAAN}

Dalam rangka menindaklanjuti ketidakdisiplinan mahasiswa, Unisma sendiri sebenarnya sudah menerapkan beberapa solusi, seperti; pembatalan nilai ujian bagi mata kuliah yang bersangkutan, tidak lulus mata kuliah yang bersangkutan, tidak diperkenankan mengikuti kegiatan akademik pada periode tertentu, bahkan dikeluarkan dari Unisma. Namun rupanya solusi tersebut dinilai belum efektif karena masih banyak ditemukan mahasiswa yang melakukan tindak ketidakdisiplinan. Sehingga diperlukanlah mesin AbCD yang dinilai cukup membantu dalam mendisiplinkan mahasiswa. Berikut ini adalah metode yang digunakan dalam program ini, yaitu: Pertama, analisis praprogram. Pada tahap pertama, kami akan mematangkan kembali konsep yang telah dirumuskan, seperti; Survey Lokasi, Administrasi Perijinan, Pengadaan Barang, Persiapan Materi, Perekrutan Fasilitator dan Peserta, Pembekalan Dosen, Penyuluhan Mahasiswa, Pemanfaatan AbCD, Dan Evaluasi.

Kedua, survey lokasi. Pada tahap kedua, kami akan melakukan survey lokasi yang layak, yang sekiranya aman untuk penempatan mesin AbCD. Sekaligus survey lokasi yang akan digunakan untuk pelaksanaan program kegiatan pembinaan dosen dan penyuluhan mahasiswa.

Ketiga, administrasi perijinan. Pada tahap ketiga, kami akan mengadakan perijinan kegiatan ke Fakultas IImu Administrasi, dan diteruskan ke pihak Universitas agar kegiatan ini berjalan sesuai dengan yang diharapkan.

Keempat, pengadaan barang. Pada tahap keempat, kami akan membeli 4 unit mesin AbCD dalam rangka ujicoba yang masing-masing akan ditempatkan di 4 kelas, yakni; 2 di kelas negara, dan 2 di kelas niaga. Pengadaan barang ini akan lebih efektif dengan kami yang secara langsung bekerjasama dengan perusahaan $A b C D$. Mesin AbCD ini juga ditempatkan di dalam kelas, bukan di luar kelas guna menghindari hal-hal yang tidak 
diinginkan. Selain itu kami juga akan membeli alat untuk meletakkan mesin $A b C D$, dan fakultas sebagai penyedia 1 unit $P C$ yang khusus digunakan untuk memonitoring keempat mesin AbCD.

Kelima, persiapan materi. Pada tahap kelima, kami akan menyiapkan materi mengenai segala sesuatu yang berkaitan dengan mesin $A b C D$, yang nantinya akan digunakan untuk pembekalan Dosen dan penyuluhan mahasiswa.

Keenam, perekrutan fasilitator dan peserta. Pada tahap keenam, kami akan merekrut fasilitator yang sudah terbilang ahli dan menguasai mengenai mesin $A b C D$, di mana fasilitator ini akan membagikan ilmunya ke Dosen dan memberikan penyuluhan kepada mahasiswa. Sementara peserta sendiri didapatkan dari mahasiswa FIA seluruh angkatan.

Ketujuh, pembekalan dosen. Pada tahap ketujuh, Dosen akan dibekali tentang cara penggunaan mesin $\mathrm{AbCD}$ oleh fasilitator. Dosen juga akan diberi kode/password untuk mengaktifkan mesin AbCD sebelum dan sesudah mata kuliah berlangsung. Sehingga dalam hal ini, mesin AbCD tidak dapat disalahgunakan oleh mahasiswa yang akan bertindak curang. Dosen juga diberi pengetahuan tentang cara menjaga kualitas mesin agar tetap terjaga dan dapat menangani mesin $\mathrm{AbCD}$ apabila terjadi kerusakan.

Kedelapan, penyuluhan mahasiswa. Pada tahap kedelapan, mahasiswa akan diberi penyuluhan atau semacam pembinaan mengenai tata cara penggunaan mesin $A b C D$ oleh fasilitator. Penyuluhan ini dilakukan secara berkala di setiap kelas FIA, dan dilaksanakan secara kontinyu setiap tahunnya.

Kesembilan, pemanfaatan AbCD. Pada tahap kesembilan, presensi menggunakan mesin $A b C D$ akan mulai diterapkan di seluruh ruangan kelas Negara dan Niaga. Presensi pada mesin AbCD selain menggunakan sidik jari juga bisa menggunakan scan kornea mata.

Kesepuluh, evaluasi. Pada tahap terakhir, kami akan mengevaluasi seluruh kegiatan program. Di mana dalam tahap ini, akan ditindaklanjuti mahasiswa yang masih diketahui melakukan tindakan ketidakdisiplinan. Selain itu evaluasi ini juga diharapkan dapat memberikan follow up untuk fakultas lain agar mesin $A b C D$ juga digunakan sebagai sarana untuk mendisiplinkan mahasiswa.

\section{HASIL DAN PEMBAHASAN Pengertian Absensi}

Absensi merupakan suatu kegiatan atau rutinitas yang dilakukan oleh seseorang untuk membuktikan dirinya hadir atau tidak hadir dalam bekerja atau belajar. Absensi adalah suatu pendataan kehadiran, bagian dari pelaporan suatu aktifitas institusi, atau komponen suatu institusi itu sendiri yang berisi data-data kehadiran yang di susun dan diatur sedemikian rupa sehingga mudah untuk dicari dan dipergunakan apabila sewaktu-waktu diperlukan oleh pihak yang berkepentingan (Simonna Erna, 2008). 
Menurut Faisal (2006), Absensi adalah pelaksanaan pengisian daftar hadir atau absensi secara manual (hanya berupa buku daftar hadir) akan menjadi penghambat bagi organisasi dalam hal ketepatan waktu datang dan pulang pegawai setiap harinya. Hal ini dikhawatirkan akan membuat komitmen pegawai terhadap pekerjaan atau organisasi menjadi berkurang. Yang mana berkurangnya komitmen tersebut akan berdampak pada motivasi dan kinerja yang semakin menurun.

Hal yang sama juga berlaku untuk mahasiswa, apabila di sebuah Perguruan Tinggi tetap memakai absensi manual berupa buku presensi, maka mahasiswa tidak sadar sepenuhnya akan tanggung jawabnya sebagai mahasiswa. Mayoritas mahasiswa akan menganggap bahwa buku presensi tak lain adalah bukti kehadiran semata, tanpa menyadari bahwa bukti kehadiran tersebut juga menentukan prestasi akademiknya.

Perbandingan antara pencatatan absensi konvensional, absensi dengan menggunakan kartu magnetik (bar code), dan pencatatan absensi dengan finger print dapat dilihat dalam tabel di bawah ini.

Tabel 1. Perbandingan Kelemahan dan Keunggulan Beberapa Pencatatan Absensi

\begin{tabular}{|c|c|c|c|c|}
\hline \multirow[b]{2}{*}{ No } & \multicolumn{2}{|c|}{ Kelemahan } & \multicolumn{2}{|c|}{ Keunggulan } \\
\hline & $\begin{array}{l}\text { Faktor-Faktor yang } \\
\text { mempengaruhi }\end{array}$ & $\begin{array}{c}\text { Kartu A bsensi dan Mes in } \\
\text { Pencetak Waktu }\end{array}$ & $\begin{array}{c}\text { Magnetic Tape } \\
\text { Reader/Bar Code Reader }\end{array}$ & $\begin{array}{c}\text { Finger Print Scanner dan } \\
\text { Software }\end{array}$ \\
\hline 1. & $\begin{array}{l}\text { Ketidakjujuran mahasiswa } \\
\text { (mahasiswa yang TA dan } \\
\text { teman yang mencatat } \\
\text { kehadiran) }\end{array}$ & $\begin{array}{l}\text { Seringkali terjadi kesalahan. } \\
\text { Kartu absensi digunakan } \\
\text { bersama-sama }\end{array}$ & $\begin{array}{l}\text { Dapat terjadi, kartu magnetic } \\
\text { dapat digunakan bersama- } \\
\text { sama }\end{array}$ & $\begin{array}{l}\text { Tidak mungkin terjadi. Sidik } \\
\text { ari tidak mungkin digunakan } \\
\text { oleh mahasiswa yang lain. }\end{array}$ \\
\hline 2. & $\begin{array}{l}\text { Manipulasi atau hilangnya } \\
\text { kartu absensi }\end{array}$ & $\begin{array}{l}\text { Mungkin terjadi. Buku } \\
\text { absensi seringkali hilang atau } \\
\text { tertukar dengan buku absensi } \\
\text { yang lain. }\end{array}$ & $\begin{array}{l}\text { Mungkin terjadi, kartu } \\
\text { magnetic dapat digunakan } \\
\text { antar mahasiswa }\end{array}$ & $\begin{array}{l}\text { Tidak mungkin terjadi } \\
\text { karena sidik jari seseorang } \\
\text { selalu unik (tidak ada yang } \\
\text { sama). Dapat menggunakar } \\
\text { lebih dari } 1 \text { jari untuk } \\
\text { identifikasi. }\end{array}$ \\
\hline 3. & $\begin{array}{l}\text { Kesalahan/ketidakakuratan } \\
\text { waktu kuliah mahasiswa }\end{array}$ & $\begin{array}{l}\text { Kurang akurat. Pencetak } \\
\text { waktu dapat diset atau reset } \\
\text { manual, sehingga pencatatan } \\
\text { menjadi tidak akurat. }\end{array}$ & $\begin{array}{l}\text { Akurat. Pencatatan waktu } \\
\text { menggunakan komputer } \\
\text { sangat akurat. }\end{array}$ & $\begin{array}{l}\text { Akurat. Pencatatan waktu } \\
\text { menggunakan komputer } \\
\text { sangat akurat. }\end{array}$ \\
\hline 4. & $\begin{array}{l}\text { Otomatisasi sistem pelaporan } \\
\text { dan integrasi dengan sistem } \\
\text { kemahasiswaan }\end{array}$ & $\begin{array}{l}\text { Secara manual., dan harus } \\
\text { dilakukan secara manual. } \\
\text { Kemungkinan kesalahan } \\
\text { penyalinan data dari kartu } \\
\text { absensi cukup besar. }\end{array}$ & $\begin{array}{l}\text { Dapat secara otomatis. } \\
\text { Mungkin dapat diintegrasikan } \\
\text { dengan sistem } \\
\text { terkomputerisasi. }\end{array}$ & $\begin{array}{l}\text { Otomatis dan terintegrasi ke } \\
\text { sistem kemahasiswaan. } \\
\text { Selalu dapat dilakukan } \\
\text { otomatisasi pelaporan., } \\
\text { menggunakan sistem yang } \\
\text { terintegrasi. }\end{array}$ \\
\hline
\end{tabular}

Sumber: http://www.lipi.informatika.go.id/jurnal/implementasi-teknologi-biometric-untuk-sistemabsensi-perkantoran / November 2005

Berdasarkan tabel di atas dapat diketahui bahwa absensi yang sangat efektif adalah absensi menggunakan finger print. Adanya Finger Print Absen mampu mencegah peluang manipulasi absen, kesalahan pencatatan, hilangnya buku presensi dan dapat menampilkan bukti kehadiran mahasiswa secara up to date. 


\section{Finger Print Absen Secara Umum}

Finger Print Absen merupakan salah satu teknologi biometrik yang paling umum digunakan. Dengan digunakannya Finger Print Absen mahasiswa diharuskan hadir pada saat perkuliahan berlangsung, sebab sidik jari merupakan identitas pribadi yang tidak mungkin ada yang menyamainya. Proses yang dilakukan dalam Finger Print Absen akan menghasilkan laporan yang dapat dibuat dengan cepat dan tepat. Sidik jari memiliki beberapa karakteristik sebagai berikut: (1) Parennial Nature, yakni: guratan-guratan pada sidik jari yang melekat pada manusia seumur hidup; (2) Immutability, yaitu: sidik jari seseorang tak akan berubah kecuali sebuah kondisi, seperti: terjadi kecelakaan yang serius sehingga mengubah pola sidik jari; dan (3) individuality, yang berarti keunikan sidik jari merupakan originalitas pemiliknya yang tak mungkin sama dengan siapapun di muka bumi ini sekalipun pada seseorang yang kembar identik.

Penelitian tentang penggunaan Finger Print Absen juga sudah banyak dilakukan dan dari hasil penelitian tersebut menunjukkan bahwa penggunaan teknologi fingerprint authentication dapat menghilangkan kecurangan dalam proses presensi. Salah satunya adalah penelitian penggunaan fingerprint sebagai media otentikasi. Dalam hal ini fingerprint absen dibandingkan dengan dua media otentikasi yang lain. Yang mana dalam hasil penelitian menyatakan bahwa teknologi biometrik finger print lebih aman, nyaman, dan lebih dapat diandalkan jika dibandingkan dengan teknik otentikasi yang lain (Khan \& Zahid, 2010). Selanjutnya, penelitian yang menganalisa penggunaan berbagai macam teknologi biometrik untuk meningkatkan kehadiran pegawai, dalam penelitian tersebut menghasilkan kesimpulan bahwa teknologi finger print adalah yang terbaik diantara teknologi biometrik yang lain (Muhtahir, Adeyinka, \& Kayode, 2013).

Mesin absensi sidik jari merupakan Sistem Informasi Manajemen yang mengandung elemen-elemen fisik seperti yang diungkapkan oleh Davis mengenai Sistem Informasi Manajemen (Widyahartono, 1992:3), yakni sebagai berikut: (1) perangkat keras komputer; terdiri atas komputer (pusat pengolahan, unit masukan/keluaran, unit/penyimpanan, file, dan peralatan penyimpanan data; (2) data base (data yang tersimpan dalam media penyimpanan komputer); (3) prosedur, komponen fisik karena prosedur disediakan dalam bentuk fisik, seperti buku panduan dan instruksi; dan (4) personalia pengoperasian, seperti: operator komputer, analisis sistem pembuatan program, personalia penyimpanan data dan pimpinan sistem informasi.

Berdasarkan survey Kevin Young yang dari PC Magazine pada tahun 2000, hampir $85 \%$ teknologi yang digunakan adalah sidik jari, meskipun ada beberapa teknologi biometrik yang lainnya, seperti; tangan, suara, retina, dan bentuk wajah. 


\section{Manfaat Penggunaan Finger Print Absen}

Penerapan Finger Print Absen tentunya memberikan banyak manfaat. Tidak hanya bagi mahasiswa, tetapi juga Dosen, penjaga gedung, bagian kemahasiswaan, maupun institusi yang menerapkannya. Berikut beberapa manfaat dari diterapkannya Finger Print Absen;

1. Menghindari penyalahgunaan daftar hadir (tidak ada titip atau rapel absen mahasiswa).

2. Obyektif (kehadiran dan durasi waktu kuliah mahasiswa tercatat).

3. Memberikan kemudahan dan kenyamanan dalam proses absensi pada mahasiswa.

4. Mengurangi pekerjaan administratif, khususnya penjaga gedung dan bagian kemahasiswaan.

5. Mahasiswa dan Dosen lebih tepat waktu karena Finger Print Absen dilengkapi dengan jadwal kuliah yang terjadwal.

6. Meningkatkan kedisiplinan dan motivasi belajar mahasiswa.

7. Meningkatkan sistem paperless pada organisasi yang dimulai dengan sistem sidik jari dan dapat mengurangi biaya dalam materi maupun operasional.

8. Memberikan informasi yang selengkap-lengkapnya kepada bagian kemahasiswaan yang berhubungan dengan kedisiplinan mahasiswa berupa absensi kehadiran yang merupakan salah satu standar penilaian dalam mengikuti mata kuliah.

9. Efektivitas waktu, seperti diketahui penggunaan Finger Print Absen pada umumnya lebih cepat daripada absensi dengan barcode atau tanda tangan. Finger Print Absen mempunyai kecepatan pembacaan kurangdari 0,5 detik dan memiliki tingkat akurasi yang tinggi.

\section{Scan Sidik Jari}

Scan sidik jari berarti kita me-scan sidik jari melalui suatu alat finger print agar dapat dibaca oleh program dengan cara menempelkan jari kita ke sensor alat fingerprint tersebut. Sistem ini meliputi sebuah alat perangkat keras scanner dan perangkat lunak yang merekam karakteristik sidik jari secara spesifik lalu menyimpan data setiap user ke dalam sebuah database. Ketika user mencoba lagi menggunakan akses maka perangkat lunak akan membandingkan data yang tersimpan pada database dengan pembacaan sidik jari dari scanner.

Sistem scan sidik jari sangat akurat akan tetapi dapat dipengaruhi oleh perubahan-perubahan di dalam sidik jari (terbakar, bekas luka, dan sebagainya), kotoran, dan faktor-faktor lain yang menimbulkan gangguan pada gambar. Pembacaan sidik jari oleh mesin finger print terdiri dari beberapa teknik, yaitu: Pertama, optik. Dalam teknik ini pola sidik jari direkam atau discan mengunakan cahaya. Alat perekam (finger print scanner) yang digunakan adalah kamera digital. Tempat untuk meletakkan ujung jari disebut permukaan 
sentuh (scan area). Di bawah scan area terdapat lampu atau pemancar cahaya yang menerangi permukaan ujung jari. Hasil pantulan cahaya dari ujung jari tersebut ke dalam memori. Kelemahan metode ini adalah hasil scanning yang sangat tergantung dari kualitas sidik jari. Jika kualitas sidik jari jelek atau luka, maka kualitas pembacaan tidak akan bagus. Kelemahan lain adalah teknik ini bisa diakali dengan jari palsu. Tetapi teknik ini memiliki keuntungan mudah dilakukan dan tidak membutuhkan biaya yang mahal.

Kedua, ultrasonik. Teknik ini hampir sama dengan teknik yang digunakan dalam dunia kedokteran. Teknik ultrasonik menggunakan suara berfrekuensi sangat tinggi untuk menembus lapisan epidermal kulit. Suara frekuensi tinggi tersebut dibuat dengan menggunakan transducer piezoelectric. Selanjutnya, pantulan energi tersebut ditangkap menggunakan alat yang sejenis. Pola pantulan ini dipergunakan untuk menyusun citra sidik jari yang dibaca. Melalui teknik ini tangan yang kotor tidak menjadi masalah. Demikian juga dengan permukaan scanner yang kotor tidak akan menghambat proses pembacaan.

Ketiga, kapasitan. Teknik ini menggunakan cara kapasitan untuk membentuk citra sidik jari. Scan area berfungsi sebagai lempeng kapasitor, dan kulit jari berfungsi sebagai lempeng kapasitor lainnya. Karena adanya ridge (gundukan) dan valley (lembah) pada sidik jari, maka kapasitas dari kapasitor masing-masing orang akan berbeda. Kelemahan ini adalah adanya listrik statis pada tangan. Untuk menghilangkan listrik statis ini, tangan harus digrounding.

Keempat, thermal. Teknik ini menggunakan perbedaan suhu anatara ridge (gundukan) dengan valley (lembah) sidik jari untuk mengetahui pola sidik jari. Cara yang dilakukan adalah dengan menggosokkan ujung jari (swap) ke scan area. Apabila ujung jari hanya diletakkan saja, dalam waktu singkat suhunya akan sama karena adanya proses keseimbangan.

Scan sidik jari akan menangkap kontur kulit jari. Kontur kulit jari adalah hal yang sangat penting karena bisa menghindari kecurangan pemalsuan dengan menggunakan foto copy sidik jari, karet atau cetakan yang lain. Biasanya 1/3 sidik jari berbentuk Whorl, 2/3 berbentuk Loop, dan 5-10\% berbentuk Arches sebagaimana gambar berikut ini:
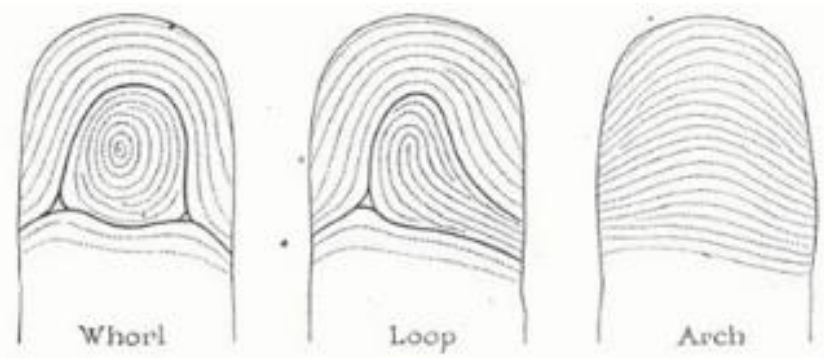

Gambar 1. Bentuk-bentuk sidik jari 


\section{Use Case Diagram}

Diagram ini memperlihatkan himpunan use case dan aktor-aktor yang nantinya terlibat dalam penerapan Finger Print Absen di lingkungan Universitas Islam Malang. Diagram ini sangat penting untuk mengorganisasikan dan memodelkan suatu sistem yang dibutuhkan. Pada sistem presensi, use case diagram memiliki 3 aktor yang terlibat, yaitu: Administrator (Bagian Akademik), Dosen, dan Mahasiswa.

Pertama, administrastor (user aplikasi presensi). Merupakan aktor yang terdiri dari bagian akademik Universitas Islam Malang, yang nantinya akan mengolah data dalam sistem presensi sidik jari mahasiswa.

Kedua, dosen. Merupakan aktor yang nantinya membuka sistem dalam mesin Finger Print Absen, sebelum perkuliahan berlangsung dan menutup sistem setelah perkuliahan selesai.

Ketiga, mahasiswa. Merupakan aktor yang menggunakan fasilitas presensi sidik jari di lingkungan Universitas Islam Malang. Use case diagram selengkapnya dapat dilihat dari diagram berikut:

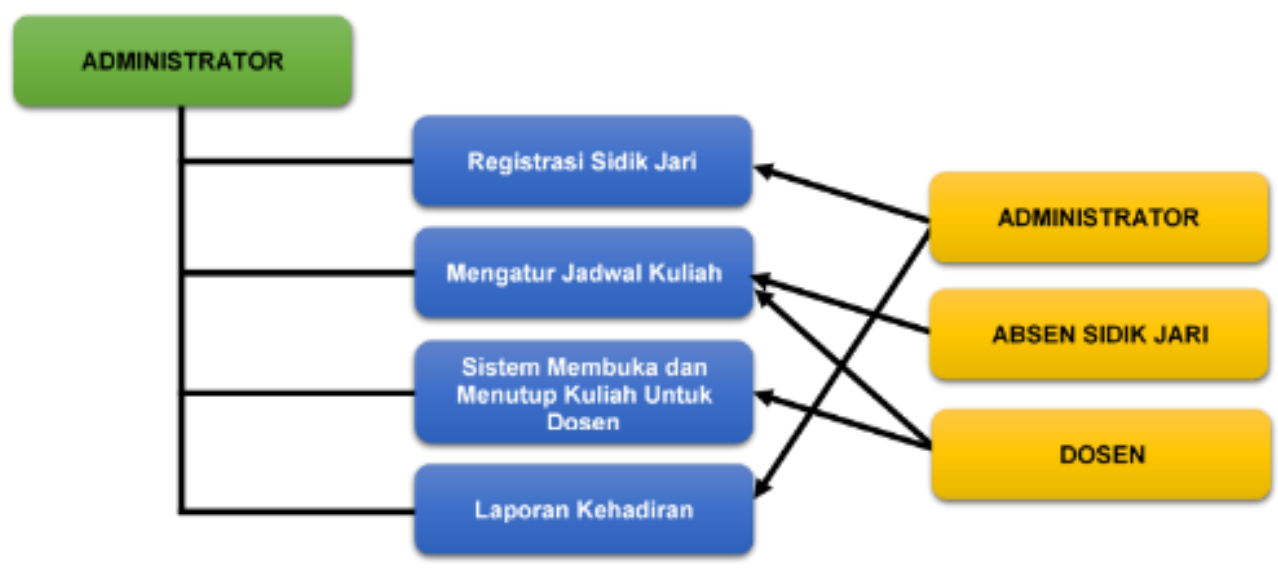

Gambar 2. Use Case Diagram

\section{Cara Penggunaan Mesin Absensi Sidik Jari}

Penggunaan mesin sidik jari bisa lebih efektif dan efisien dalam penyelenggaraan perkuliahan dan dapat meningkatkan disiplin mahasiswa. Cara penggunaannya adalah sebagai berikut:

Pertama, registrasi atau pendaftaran sidik jari. Merupakan proses yang menentukan dalam keberlangsungan proses absensi mahasiswa. Proses ini harus dilakukan dengan benar khususnya penempatan jari saat pendaftaran pada mesin. Sebelum melakukan proses registrasi, terlebih dahulu dibuat Rancangan Menu Utama, yang berisi data Mahasiswa, seperti: Nama Mahasiswa, Tempat Tanggal Lahir, NPM, Jurusan, Fakultas, dan Angkatan.

Kedua, download data dan sidik jari mahasiswa. Untuk membackup data sidik jari dan memberikan nama mahasiswa agar muncul pada mesin 
Finger Print Absen, maka langkah selanjutnya yang harus dilakukan adalah dengan mendownload sidik jari dan data mahasiswa dari software ke mesin Finger Print Absen. Sebelum mendownload pastikan kondisi mesin Finger Print Absen dengan software telah terkoneksi.

Ketiga, upload data mahasiswa di bagian kemahasiswaan. Untuk mensinkronisasi data, setelah menginputkan nama mahasiswa pada mesin Finger Print Absen, selanjutnya adalah mengupload data mahasiswa. Dengan sistem ini kebenaran sidik jari yang digunakan mahasiswa akan sesuai dengan mahasiswa yang bersangkutan.

Keempat, pengaturan jam kuliah. Jam atau jadwal kuliah nantinya akan digunakan untuk menampilkan laporan kuliah. Pengaturan jam kuliah ini bisa dilakukan oleh Dosen, atau berdasarkan kesepakatan antara Dosen dan mahasiwa. Apabila jadwal kuliah sudah disepakati atau telah ditentukan maka bagian kemahasiswaan akan memasukkannya ke dalam database dan dapat disinkronkan dengan mesin Finger Print Absen.

Kelima, kalkulasi laporan. Setelah semua proses dilakukan, proses terakhir adalah membuat laporan absensi. Dalam hal ini cukup mengatur instansi/bagian, nama mahasiswa, dan rentang waktu yang akan dibuat laporan. Untuk membuat laporan software absensi pada umumnya sudah dilengkapi dengan pengaturan rentang waktu laporan yang bisa diatur harian, mingguan, bulanan, sampai tahunan.

\section{Model Finger Print yang Ditawarkan}

Penggunaan model finger print yang diterapkan menjadi lebih baik dan efektif dilihat dari perbandingan antara model absensi yang sudah diterapkan dan alternative yang akan diterapkan. Pertama, model absensi manual yang selama ini diterapkan di Unisma seperti dalam gambar di bawah ini.

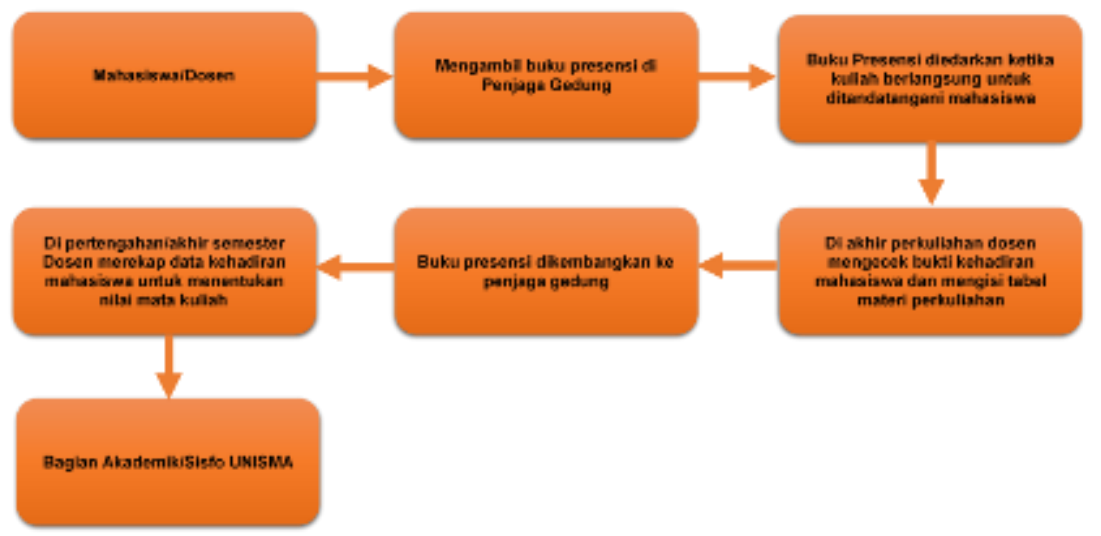

Gambar 3. Model Absensi yang Selama ini Diterapkan di UNISMA

Seperti diketahui selama ini absensi yang digunakan mahasiswa di Universitas Islam Malang masih memakai absensi manual, sebagaimana tercantum dalam diagram di atas, yaitu: (1) sebelum perkuliahan, Dosen atau 
mahasiswa mengambil buku presensi di penjaga gedung; (2) selama perkuliahan berlangsung, buku presensi diedarkan untuk ditandangani mahasiswa. Dalam hal ini biasanya Dosen yang tegas tidak sembarangan mengedarkan buku presensi tersebut. Biasanya di awal kuliah atau di akhir kuliah Dosen yang tegas akan memanggil nama mahasiswa satu per satu, sehingga mahasiswa yang benar-benar datang atau tidak akan ketahuan. Sebaliknya, ada pula Dosen yang sembrono dengan mengedarkan buku presensi tersebut di sela-sela kuliah berlangsung. Sehingga mahasiswa bisa saja bertindak curang dengan mengisi absensi temannya yang tidak hadir. Selain itu, buku presensi yang diedarkan ketika kuliah berlangsung sudah pasti sangat tidak efektif karena menggangu proses perkuliahan, dan mahasiswa tidak fokus menerima mata kuliah tetapi juga mencari buku presensi; (3) setelah perkuliahan selesai, Dosen atau mahasiswa akan mengembalikan buku presensi ke penjaga gedung. Pada proses pengembalian ini sangat rentan sekali buku presensi hilang, mengingat penjaga gedung biasanya hanya memiliki waktu kerja sampai pukul 14.00 WIB. Dengan begitu mahasiswa yang kuliah sore tentu akan kesulitan untuk absen, sedangkan mahasiswa yang telah menyelesaikan perkuliahan biasanya tidak jadi mengembalikan buku tersebut, melainkan dibawa pulang; (4) pada periode tertentu, seperti : pertengahan semester atau akhir semester biasanya Dosen akan merekap ulang data kehadiran mahasiswa untuk menentukan nilai mata kuliah. Yang mana nilai tersebut akan ditampilkan di bagian akademik atau sisfo Unisma.

Dengan demikian, maka dapat dikatakan bahwa absensi manual yang selama ini ada di Unisma sangat tidak efektif. Sebab, absensi manual tersebut rentan disalahgunakan mahasiswa, rentan hilang, dan tidak up to date mengingat laporan kehadiran mahasiswa hanya dihitung pada periode tertentu, dan tidak langsung pada hari yang sama saat mahasiwa hadir mengikuti kuliah.

Kedua, alternatif model penggunaan finger print yang bisa diterapkan dengan skema dan model seperti di bawah ini.

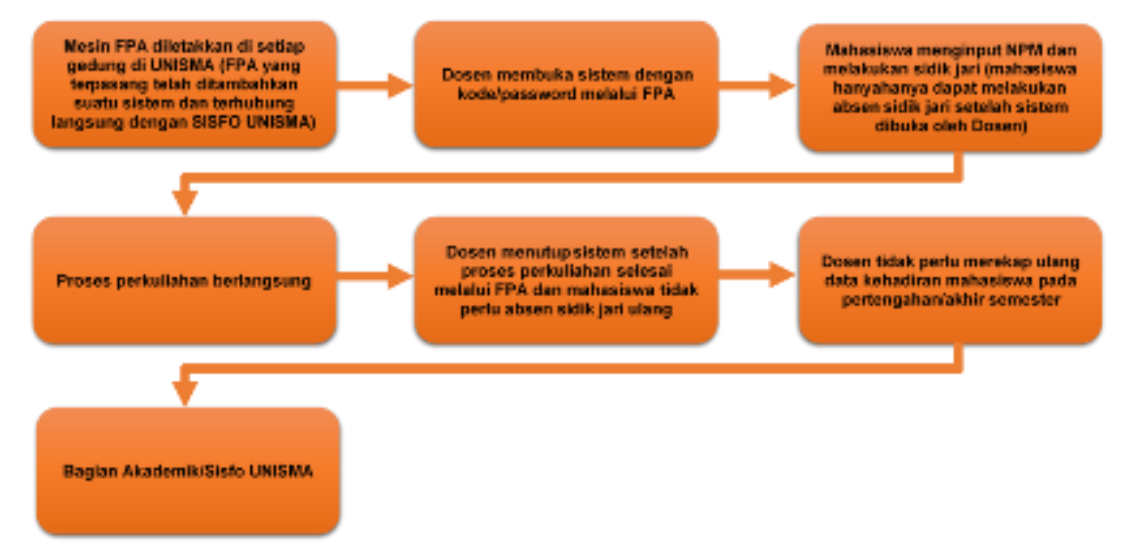

Gambar 4. Model Absensi Finger Print yang Akan Diterapkan di UNISMA 
Model absensi Finger Print yang akan diterapkan di Unisma adalah sebagai berikut: (1) mesin finger print absen akan diletakkan di setiap gedung di Unisma. Tentunya mesin ini sudah dipasangkan dengan suatu sistem yang terhubung langsung dengan sisfo Unisma; (2) sebelum kuliah berlangsung, Dosen membuka sistem dengan kode/password melalui mesin Finger Print Absen yang terdiri dari 6 digit. Yang bisa membuka dan menutup sistem ini adalah Dosen, sehingga mahasiswa tidak bisa menyalahgunakan mesin Finger Print; (3) setelah dosen berhasil membuka sistem, mahasiswa baru dapat menginput NPM dan melakukan sidik jari. Dengan demikian proses perkuliahan bisa berlangsung dengan lancar tanpa adanya gangguan dari peredaran buku presensi; (4) setelah perkuliahan selesai, Dosen kembali menutup sistem sebagai tanda perkuliahan telah selesai dilakukan. Sementara mahasiswa tidak perlu melakukan absen sidik jari ulang; (5) adanya mesin Finger Print Absen dapat mengurangi pekerjaan Dosen, sebab pada pertengahan atau akhir semester, Dosen tidak perlu merekap kembali laporan kehadiran mahasiswa. Mengingat, setiap mata kuiah berlangsung dan setiap mahasiswa presensi melalui mesin Finger Print Absen maka saat itulah data otomatis terekam di dalam database sisfo unisma, baik Dosen, mahasiswa, maupun bagian akademik Unisma secara langsung dapat memonitor presensi kehadiran mahasiswa.

Dengan demikian mesin Finger Print Absen dapat dikatakan sangat efektif karena dapat membantu mendisiplinkan mahasiswa. Baik mahasiswa maupun Dosen akan terbiasa pula disiplin waktu, karena jadwal kuliah telah disetting oleh mesin Finger Print Absen. Di samping itu, sisfo Unisma akan menyajikan data yang up to date terkait kehadiran mahasiswa.

Untuk mahasiswa yang tidak melakukan absensi otomatis akan tercatat tidak hadir. Kalau pun mahasiswa tersebut tidak masuk karena sakit, sedang ikut kegiatan UKM, dan lain sebagainya harus menyertakan surat ijin. Yang mana surat ijin tersebut harus dalam bentuk fisik dan sampai di tangan Dosen untuk di sampaikan ke bagian akademik Unisma. Sehingga pada presensi kehadiran, mahasiswa tersebut bukan tercatat tidak hadir, melainkan izin.

\section{Activity Diagram Finger Print Absen}

Mesin Finger Print Absen memiliki sensor yang berguna sebagai pemindai sidik jari, di mana sensor finger print memiliki tingkat sensitif yang tinggi. Sensor akan melakukan proses scan pemindaian untuk setiap jari tangan yang mengenai sensor tersebut, dan data dari hasil scan akan dikirimkan ke komputer melalui USB. Setelah dilakukan suatu registrasi untuk satu jari maka data tersebut akan tersimpan dalam database yang terdapat pada komputer.

Proses pendaftaran sidik jari adalah dengan menempelkan 3 sidik jari yang berbeda ke permukaan sensor yang hendak di daftar, yakni: ibu jari, jari telunjuk, dan jari tengah. Namun pada saat proses verifikasi, si pengguna cukup menempelkan salah satu dari ketiga jari tersebut ke permukaan sensor. Selanjutnya sensor akan mengirimkan data hasil baca sensor ke komputer. 
Apabila data hasil baca memiliki kesamaaan ciri dengan data yang ada dalam basis data maka proses verifikasi berlangsung sukses. Sedangkan, apabila data hasil baca tidak menemukan adanya kesamaan ciri dengan data yang ada pada database, maka proses akan ditolak atau dengan kata lain proses verifikasi gagal. Jika proses verifikasi gagal, mahasiswa dapat mengganti menempelkan kedua jari yang lain secara bergantian sampai proses verifikasi berhasil. Namun apabila mahasiswa sudah menempelkan ketiga jarinya, dan proses verifikasi masih gagal, maka mahasiswa dapat segera melaporkannya ke bagian kemahasiswaan untuk segera ditindaklanjuti. Sebab jika tidak, maka mahasiswa akan dianggap tidak hadir pada saat mata kuliah berlangsung. Aktifitas diagram absensi sidik jari dapat ditampilkan dengan diagram berikut ini.

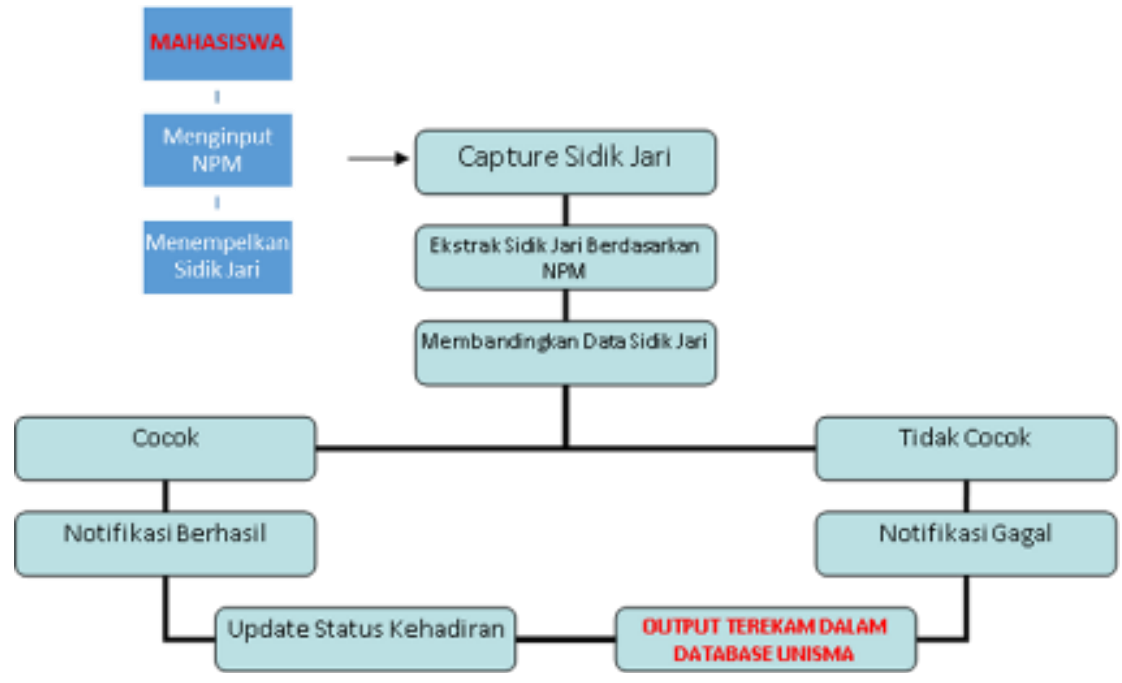

Gambar 5. Aktivitas Diagram Absensi Sidik Jari

\section{Kendala dan Solusi yang Mungkin Muncul}

Setiap kebijakan atau alternative juga tidak lepas dari kelemahan dan kekurangannya, karena hal itu menjadi bagian yang tidak terpisahkan dalam kehidupan. Alternatif dari penggunaan finger print ini juga pasti ada kendala yang mungkin terjadi. Oleh karena itu, penulis juga mengantisipasinya dengan solusi yang ditawarkan. Pertama, Bagaimana proses absensi jika Dosen tidak hadir namun kuliah harus tetap berlangsung dengan mengerjakan tugas atau diskusi kelompok? Mengingat yang dapat membuka atau menutup sistem dalam mesin Finger Print Absen hanyalah Dosen.

Solusinya adalah Dosen dapat mempercayakan proses pembukaan sistem pada mesin finger print absen kepada asisten dosen atau seseorang yang telah dipercaya oleh Dosen tersebut. Dengan demikian mahasiswa tetap dapat mengisi absensi melalui Finger Print Absen. 
Kedua, bagaimana jika listrik tiba-tiba padam, apakah mesin Finger Print Absen tetap bisa digunakan. Solusinya adalah mesin finger print absen dipasangi baterai. Sehingga pada saat listrik padam, mesin finger print absen tetap bisa digunakan.

Ketiga, bagaimana jika ada mahasiswa yang menyalahgunakan mesin Finger Print Absen, misalnya; dengan sengaja merusak atau mencuri mesin finger absen. Solusinya adalah mesin finger print absen diletakkan di ruangan yang dijangkau CCTV, sehingga baik mahasiswa tidak ada yang menyalahgunakan mesin Finger Print Absen tersebut. Kalau pun ada, maka pihak kampus bisa segera melacaknya dan menangkap pelaku dari rekaman CCTV tersebut.

Keempat, bagaimana jika jadwal kuliah bersamaan dengan Dosen lain, yang menyebabkan antrian pada saat mahasiswa melakukan absensi di depan mesin Finger Print Absen. Solusinya adalah dosen dibantu bagian kemahasiswaan dapat mengeset ulang jadwal perkuliahan dengan selisih waktu 10-15 menit selanjutnya, sehingga mahasiswa dapat melakukan absensi tanpa mengantre.

Kelima, bagaimana jika ada mahasiswa yang curang saat absen sidik jari, misalnya: mata kuliah Administrasi Perkantoran Modern dimulai pada pukul 09.00-10.30. Namun mahasiswa tersebut hanya datang untuk sekedar absen pada pukul 09.30 lalu pulang dan tidak mengikuti mata kuliah.

Solusinya adalah sistem pada mesin Finger Print Absen dijadwal hanya berselang selama 10 menit setelah dibuka oleh Dosen. Sehingga durasi untuk absen sidik jari hanya berlangsung sampai pukul 09.10. Jadi, mahasiswa yang absen melebihi batas waktu yang ditentukan atau lebih dari 10 menit, meskipun ia telah absen namun pada sistem tetap terekam tidak hadir.

\section{KESIMPULAN}

Penggunaan finger print bagi mahasiswa Fakultas IImu Administrasi Universitas Islam Malang secara umum akan memberikan dampak positif bagi mahasiswa. Kedisiplinan dalam kuliah menjadi penting dalam rangka untuk meningkatkan kualitas pendidikan dan karakter mahasiswa. Melalui pengaturan kedisiplinan ini diharapkan dapat berdampak secara sistematik terhadap paradigm mahasiswa dan terhadap system di fakultas ilmu administrasi, serta dapat pula dijadikan secara role model bagi seluruh fakultas di lingkungan universitas islam malang. Di samping itu, aspek efisiensi dan efektifitas penyelenggaraan pendidikan dan pengajaran lebih terukur dan dapat dikontrol secara penuh melalui system yang bergerak secara otomotis, sehingga fokus dosen dalam peningkatan kualitas pengajaran dan pendidikan terhadap mahasiswa bisa lebih maksimal. 


\section{DAFTAR RUJUKAN}

Ahmad, Faisal. 2006. Hubungan Penerapan Absensi Sidik Jari (Finger Print) dengan Motivasi dan Kinerja Karyawan. Bogor : Skripsi Institut Pertanian Bogor.

Anonim. 2012. Sidik Jari- Review Teknologi Analisa Sidik Jari \& Mesin Fingerprint. http://sidik-jari.com. (Diakses tgl. 29-09-2014).

Fakih, Abduloh, dkk. 2015. Pemanfaatan Teknologi Fingerprint Authentication untuk Otomatisasi Presensi Perkuliahan. Surabaya : Journal of Information Engineering and Business Intelligence, Universitas Airlangga.

Lukman, Mediya. 2013. Badan Layanan Umum Dari Birokrasi Menuju Korporasi. Jakarta: Bumi Aksara.

Muhammad, Irfan. 2011. Jurnal Penggunaan Finger Print Absen Sebagai Sarana Pembaharuan Presensi di Fakultas Teknik Universitas Negeri Malang. www.academia.edu. (Diakses tgl. 22-09-2014).

Ngantung, K.A, dkk. 2014. Desain dan Implementasi Sistem Absensi Fingerprint di Jaringan Kampus dan Terintegrasi Dengan Sistem Informasi Terpadu UNSRAT. Manado : Universitas Sam Ratulangi.

Prista, Ditha. 2013. Kampus Butuh Finger Print Untuk Si Tukang Titip Absen. http://kampus.okezone.com. (Diakses tgl. 22-09-2014).

Rizqi. 2013. 9 Alasan Klasik Malas Kuliah. http://studyinjogja.com. (Diakses tgl.22-09-2014).

Saleh, Abdul Rahman. 2006. Jurnal Pengaruh Finger Print Absen Sebagai Upaya Peningkatan Motivasi dan Kinerja Karyawan. www.academia.edu. (Diakses tgl. 22-09-2014).

Sina, Muhammad. 2016. Efektifivitas Pemasangan Absen Sidik Jari (Finger Scan) Dalam Meningkatkan Disiplin Kerja Pegawai Rektorat Universitas Mulawaran Samarinda. Samarinda: Jurnal IImu Pemerintahan Universitas Mulawarman.

Wibawa, Samodra. 2005. Reformasi Administrasi-Bunga Rampai Pemikiran Administrasi Negara/Publik. Yogyakarta: Gaya Media. 